\title{
Histopathological Findings of Age-Related Kidney Lesions in Inbred Strain Fischer-344/Yit Rats
}

\author{
Kazumi UCHIDA, Masaharu ONOUE, Tokutaro TAKAHASHI, \\ Nobuo KUSANO and Masahiko MUTAI \\ Yakult Institute for Microbiological Research, \\ 1796, Yaho, Kunitachi, Tokyo 186, Japan
}

(Received for publication : May 7, 1979)

\begin{abstract}
Age-related kidney lesions were studied in male and female inbred strain Fischer-344/Yit rats of 4, 9, 25, 52 (male rats only) and 71 weeks of age. The lesions that represent probably early stage of chronic nephropathy were observed in 9-week-old rats, and also hyaline casts characteristic of chronic nephropathy occurred for the first time in 52-week-old male rats.

In males, degeneration of convoluted tubular epithelial cells, occurrence of hyaline droplets and eosinophilic bodies in proximal convoluted tubular epithelinm were already observed at 9 weeks. At 25 weeks, these lesions were most pronounced, with yellowish-brown epithelial cells in the proximal convoluted tubulus, and erythrocyte-like structure were observed occasionally in the lumen, in the epithelial cells or in the Bowman's spaces. Some of the eosinophilic bodies were positive with hemoglobin staining. In glomerulus, increase of mesangial cells and thickening of basement membrane were recognized. At 52 weeks, glomerular lesions were attended with mild fibrosis, and the hyaline casts were found in dilated tubulus of corticomedullary area. Hemosiderin deposits and appearance of brown pigment were seen in the proximal convoluted tubular epithelium. At 71 weeks, glomerular lesions, hyaline casts, hemosiderin deposits and increase of interstitial connective tissue became more severe, and also slight infiltration of lymphocytes were observed in the interstitial tissue.

Above-mentioned lesions found in male animals were also seen in females but the changes were very mild in females with the exception of the occurrence of brown pigment. In females, calcified casts were found in tubulus of corticomedullary area at 71 weeks.
\end{abstract}

\section{Fischer-344/Yit ラットの加柃にともなう \\ 腎病変の組織病理学的所見 \\ 内田和美・尾上正治・高橋徳太郎 \\ 草野信罗・務台方楌 \\ 株式会社ヤクルト本社研究所}

近年ラットを用いた長期飼育実験が，多く行なわれる よらになってきている。その際に認められる非腫痬性自 然発生病変の中で, 特に種々の名で報告されている腎病
変 $[2,4,6,8,10,13,15,18,19,21-24]$ が, ラットの死因と も関係が深いことから大きな問題となっている。しかし， ラットの自然発生腎病変に垫められる残変の性質および 
程度の診断基準については，明確なものが示されていな いため, 研究者によりその発生時期および発生率はまち まちに報告されてきた。また，ラットの系統に関しては SD ラットおよび Wistar ラットの自然発生腎病変に 関する報告に比べて，Fischer ラットに関する報告が 少ない様に思われる。そこで著者等は, Fischer ラット について，加齢と共に認められる腎病変を観察し， SD ラット $[2,17,21,23]$, Wistar ラット $[1,22]$ で報告さ れている病変と同様の変化を認め, 合わせてラット慢性 腎症の経時的推移について検討したので報告する。

\section{材料および方法}

ヤクルト研究所において20代以上兄妹交配した Charles River 由来の Fischer-344 (Fischer-344/Yit と して登録予定, 以下 F-344/Yit と略記）ラット雄48例 と倠20例を実験に使用した。

動物は金綱製ケージ $(370 \times 260 \times 180 \mathrm{~mm})$ に 5 例づつ収 容し, 室温 $24 \pm 1^{\circ} \mathrm{C}$, 湿度 $55 \pm 5 \%$ 普通の環境下で, 滅菌 NMF 飼料（オリエンタル酵母工業株式会社）と 水道水を自由に摂取させて飼育した。

\section{組織病理学的検查}

雄ラットは 4, 9, 25, 52 およよ゙7 1 週秢, 雌ラットは 4, 9, 25および71週秢で，それぞれ断頭放血により屠殺した。 摘出した腎臟は10\%中性ホルマリン液で固定した後，パ ラフィン包埋し，厚さ $3 \sim 5 \mu$ の組織切片を作成し， Hematoxylin-Eosin (H-E) 染色, Mallory 染色, Periodic acid-Schiff (PAS) 染色および1部のもの に鉄染色 (Prussian blue), hemoglobin 染色 (Ralph 法, Putt 法)を行なって観察した。

\section{成}

各週龄時における諸変化は以下に述べる如くである。 雄の腎臟に拝められる組織病理学的所見

4 週齢

特徵的な変化は認められなかった。

9 週齿

主部永細管上皮細胞は高さが不揃いとなり細胞質内に eosin に濃染する硝子滴 (hyaline droplet) を認めた (Fig. 1)。この変化の進んだところでは，上皮細胞の刷 子縁が脱落し，細胞質内に H-E 染色で eosin に染ま る物質 (eosinophilic body) を認め (Fig. 2)，その 周巡の上皮細胞に hyaline droplet が多数琵められた。
上皮の变化がさらに進んだところでは，管腔に上皮細胞 の脱落が認められた (Fig. 3)。上皮の変性の程度は, 1 つの瓜細管の断面においても一様でなく, 変性の強い ところと弱いところが混在していた。 hyaline droplet は円形で, 大きさは微細顆粒状のものから上皮細胞核よ りやや小さめなものまであり, PAS 染色に陽性で細胞 内に多数存在した。このような硝子滴を含む細胞は $1 つ$ の尿細管の断面に散在していた。また, 上皮細胞の変性 がみられない尿細管においても, hyaline dropletは認 められることがあった。eosinophilic body は不整形 で，大きさは上皮細胞核よりやや小さめなものから核の 倍程度のものまであり, PAS 染色に陰性で 1 細胞内に 1 つ認められ，細胞質との間に空隙を認めることが多く， 時には管腔に遊離してみられる像もあった。多くの場合 1 つの尿細管の断面に eosinophilic body は $1 \sim 2$ 個 認められた。上皮細胞に変化のみられる尿細管腔内には， 蛋白性の物質の凝塊と考えられる eosin 染まる網目状 の構造がときおり認められ (Fig. $4 \mathrm{~A}$ ), 同様の構造は 系球体烡間腔内にも認められた (Fig. 4 B)。前述の尿 紐管に琹められる変性上皮, hyaline droplet および eosinophilic bodyは Mallory 染色でオレンジ色から 赤色に染まり,ネフロン単位に散在していた。糸球体に は著明な変化が認められなかった。

25 週齢

9 週龄で観祭されたと同じような尿細管病変がより多 くの尿細管にみられ病変の程度も重度であった。尿細管 上皮の変性が強いところでは, $\mathrm{H}-\mathrm{E}$ 染色で黄褐色調を おびる上皮細胞（Fig. 5)（鉄反応陰性）が認められた。 また，尿細管腔，尿細管上皮細胞内または糸球体襄間腔 内に, 赤血球様の小体を認めた (Fig. 6)。この小体と 1 部の eosinophilic body は hemoglobin 染色陽性で あった。系球体では,メサンジウム細胞の增加と基底膜 の肥厚がわずかに認められた (Fig. 7)。

52 週齢

皮髄境界部の数筒所の尿細管内に, ラット慢性腎症に 特徵的な hyaline cast の貯留が認められた (Fig. 8)。 尿細管上皮では hyaline droplet や eosinophilic body の出現は25週路に比べて軽度であったが，黄褐色調をお びる上皮細胞は多く認められるよらになった。また，上 皮細胞内にへモジデリン沈着 (Fig. 9) と，大小不同の 褐色の小体（Fig. 10）（鉄反応陰性, PAS 陰性）が認 められた。系球体では，25週秢で認められたメサンジウ 么細胞の增加と基底膜の肥厚が強くなる傾向を示し, 線 維化の恋められるものもあった。また，1部の糸球体で 
Table 1. Histopathological findings in kidney of F-344/Yit male rats at different ages.

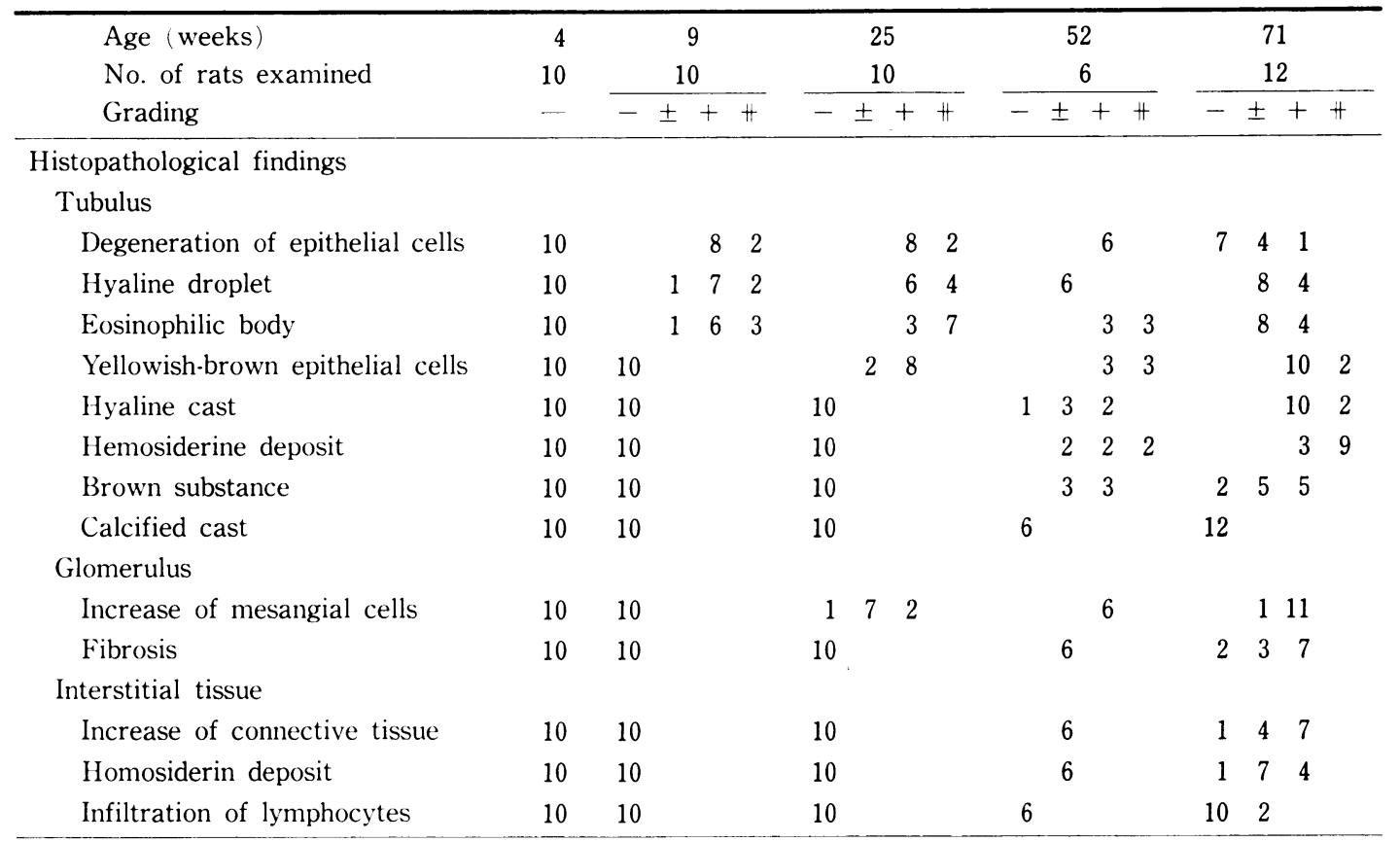

Remarks : - ; No lesions, \pm ; Slight lesions in local areas, + ; Moderate lesions over a wide area, \#; More severe lesions than + .

ボウマン囊との檷着が羿められた（Fig. 11)。間質では, 軽度の 結合組織の増生とへモジデリン沈着が恝められ た。

\section{1 週龄}

hyaline droplet, 黄褐色調をおびる上皮細胞および 褐色の小体の出現などは, 52 週齢と同程度であったが eosinophilic body の出現は 52 週齢のものより軽度で あった。他の変化については52週齢に比べて強くなって いく傾向が認められた。また， 2 例の間質にごく軽度の リンパ球を主体とする細胞浸潤が認められた。

雌の腎臓に認められる組織病理学的所見

\section{4 週龄}

特徴的な変化は認められなかった。

\section{9 週㱓}

尿細管上皮の変性の程度が雄に比べてきわめて軽度で あった他, eosinophilic body が 1 例のごく少数の尿 細管上皮細胞に認められた。

\section{5週齢}

上皮の変性の程度は 9 週秢のものとほとんど変わらず, hyaline droplet や eosinophilic body も垫められな かった。しかし，㽷細管上皮紲胞に52週柃の雄と同様の
褐色の小体が認められた。糸球体ではメサンジウム細胞 の増加が認められ，その程度は雄の同週齢のものより軽 度であった。

\section{1 週齢}

上皮の変性は25週齢に比べて強くなる傾向を示し，そ の程度は雄の 9 週齢および25週齢と同程度であった。し かし, hyaline droplet や eosinophilic body はわず かに恋められたにすぎなかった。また，皮髄境界部近く の数筒所の尿細管内に, 52 週齢の雄と同程度の hyaline cast の貯留が認められ，2 例のものに石灭化した cast (Fig. 12) が認められた。糸球体ではメサンジウム細胞 の増加と基底膜の肥厚が認められたが，52週跲の雄に比 ベて軽度なものであった。間質ではリンパ球を主体とす る小範井の細胞浸潤と結合組織の増生が軽度に認められ た。

\section{考察}

今回の奏験で F-344/Yit ラットでは自然発生腎病変 は9 週粭より認められた。尿細管腔に認められた網目状 の構造は螌白性物質の凝塊であると考えられるが，糸球 
Table 2. Histopathological findings in kidney of F-344/Yit female rats at different ages.

\begin{tabular}{|c|c|c|c|c|c|c|c|c|c|c|c|}
\hline \multirow{3}{*}{$\begin{array}{l}\text { Age (weeks) } \\
\text { No. of rats examined } \\
\text { Grading }\end{array}$} & \multirow{3}{*}{$\begin{array}{r}4 \\
5 \\
-\end{array}$} & \multirow{2}{*}{\multicolumn{3}{|c|}{$\begin{array}{l}9 \\
5\end{array}$}} & \multirow{2}{*}{\multicolumn{3}{|c|}{$\begin{array}{r}25 \\
5 \\
\end{array}$}} & \multirow{2}{*}{\multicolumn{3}{|c|}{$\begin{array}{r}71 \\
5 \\
\end{array}$}} & \multirow[b]{3}{*}{ H } \\
\hline & & & & & & & & & & & \\
\hline & & - & \pm & + & - & \pm & + & - & \pm & + & \\
\hline \multicolumn{12}{|l|}{ Histopathological findings } \\
\hline \multicolumn{12}{|l|}{ Tubulus } \\
\hline Degeneration of epithelial cells & 5 & & 4 & 1 & 1 & 3 & 1 & 4 & & 4 & 1 \\
\hline Hyaline droplet & 5 & 5 & & & 5 & & & 4 & 1 & & \\
\hline Eosinophilic body & 5 & 4 & 1 & & 5 & & & 2 & 1 & 2 & \\
\hline Yellowish-brown epithelial cells & 5 & 5 & & & 5 & & & 4 & 1 & & \\
\hline Hyaline cast & 5 & 5 & & & 5 & & & & 4 & 1 & \\
\hline Homosiderin deposit & $*$ & $*$ & & & $*$ & & & $*$ & & & \\
\hline Brown substance & 5 & 5 & & & & & 5 & & & & 5 \\
\hline Calcified cast & 5 & 5 & & & 5 & & & 3 & 2 & & \\
\hline \multicolumn{12}{|l|}{ Glomerulus } \\
\hline Increase of mesangial cells & 5 & 5 & & & 4 & 1 & & & & 5 & \\
\hline Fibrosis & 5 & 5 & & & 5 & & & 5 & & & \\
\hline \multicolumn{12}{|l|}{ Interstitial tissue } \\
\hline Increase of connective tissue & 5 & 5 & & & 5 & & & 4 & 1 & & \\
\hline Hemosiderin deposit & $*$ & $*$ & & & $*$ & & & $*$ & & & \\
\hline Infiltration of lymphocytes & 5 & 5 & & & 5 & & & 4 & 1 & & \\
\hline
\end{tabular}

Remarks : - ; No lesions, \pm ; Slight lesions in local areas, + ; Moderate lesions over a wide area, \# ; More severe lesions than,$+ *$; Not observed.

体撉間腔内にも諗められることから，おそらく糸球体基 底膜の 透過性の増加と関係しているものと思われる。 Couser 等 [7]はラット慢性腎症において, 加齢と共に 系球体基底膜の透過性が増加することを報告している。 著者等はSD ラットでは尿蛋白が34日齢で琹められ，そ の後増加する傾向のあることをすでに報告した $[17]$ 。ま た, Perry [18] 拈よび Weaver [24] 等は，尿蛋白の 主要分画がアルブミンであることを報告している。主部 录細管上皮の変化は25週齢で最も著明となり，これを境 に隇退して行く傾向がみられた。これらの変化はラット 慢性腎症と同様に雄に著明でネフロン単位に発生し，ま た, hyaline cast は皮髄境界部の尿細管に発生してい た。このようなことから推測すると, eosin に染まる網 目状の構造物や変性脱落した上皮などが皮髄境界部の尿 細管腔に停滞貯留し，それらが一旦貯留し始めると，そ の後は初期に認められた病変とは無関係に進行し, 次で hyaline cast の貯留, 糸球体の線維化拈よび間質結合 組織の增生などの諸変化に進展して行くものと考えられ る。しかし, 上述の初期変化の原因発生については不明 である。 hyaline droplet や eosinophilic body は, 雌で 9 造齢の 1 例と 71 速柃にわずかに認められたにすぎ
ず，雌雄差が著明に認められた。 hyaline droplet は 小林 $[13]$, Gray $[10,11]$ 等の言 5吸収された蛋白滴 と同一のものである。 eosinophilic body は二木 [16] が Wistar ラットの雄で報告しているもので, わずか な数ではあるが倠にも認められた事は興味深い。この小 体を著者等は, 82日㱓の雄ラット（JCL-SD）にも認め ている [17]。今回 hemoglobinを染めるベンチジン反 応 (Ralph 法, Putt 法) を試みたところ, eosinophilic body の 1 部に陽性を示すものが認められ, また, 尿細管腔，上皮細胞または糸球体䯧間腔内にときおり hemoglobin 染色陽性の赤血球様の小体を認めた。そ の発生機序は不明であるがこれらの小体は赤血球と何ら かの関係があるものと思われる。尿細管上皮細胞に护け る褐色の小体の出現は, 雄に比べて雌に早期に認められ, その程度も強く, また, 加齡と共に増強の傾向を示し た。Coleman 等 [6] の報告によれば, F344 雄ラット では150日㱓で尿細管上皮の細胞質に lipochrome pig. ment が認められ, その後加路と共に増加して, 重度な ものではへモジデリン顆粒を附随するとし又, Snell [22] は F344 および ACI ラットで Prussian blue と PAS 陰性の yellowish-brown lipochrome gra- 
nules を報告している。われわれの観察した褐色の小体 は彼らの報告と同様の物質ではないかと考えられる。へ モジデリン沈着は52週齢の尿細管上皮細胞と間質細胞に 認め，加齢と共に増加する傾向を認めた。へモジデリン 沈着について Gray [11] は基底膜の肥厚により萎縮し た近位尿細管上皮細胞内にとき拈り確認されるとし， Snell [22]は老齢ラットで小量のへモジデリンが近位尿 細管上皮細胞に恋められると報告している。

ラット慢性腎症の特徴的病変である hyaline cast の 貯留は，雄で52週齢から，雌では71週齢に皮髄境界部の 尿細管腔に認められた。この変化は, Coleman 等 [6] の grade 2 に対応するもので，彼らの F344 および Snell [22] の F344 の成績と類似していた。また，先 駆者等の報告 $[2,4,5,15,17,22,23]$ と同様に加齢と共に 增加していく傾向が認められた。 cast の発生時期につ いては，他系統である SD ラット $[2,17,21,23]$ 抽よび Wistar ラット $[1,22]$ の報告と比較するといくらか遅 く，系統差があるように思われ，また，性差も認められ た。

系球体病変について，Gray [11] は小さな cast が 集合管に認められる時期には尿細管および糸球体に变化 が認められないとし，村岡等 [15］は軽度なものに糸球 体の変化はないと報告している。また，田中等［23］は 軽度の尿細管变化のみの腎では, 糸球体の変化は之しい としている。これに対し，Bras [14]，Couser [7] お。 よび Hirokawa [12]等は早期の病変として, 系球体 に注目し, Andrew [1], Simms [21], Foley [9], Berg [2] および Hirokawa [12]等は, 糸球体病変が 尿細管病変に先行することを指摘している。今回の観察 で F-344/Yit ラットでは雌雄共に，25週龄からメサン ジウム 細胞と 糸球体基底膜の 肥厚などの 糸球体病変が cast に先行して認められることから，慢性腎症の発生 には糸球体病変が関与しているものと思われる。

今回の実験では, end stage と思われる cyst の形 成や，重度な糸球体の線維化と間質結合組織の増生およ び広範囲な細胞浸潤などは認められなかった。Coleman 等[6]の報告では, end stage は 18〜24 ケ月齢に 1 例 (2.5\%) だけ認められ，その後增加する傾向があるとし ている。今回の実験では, 観察を71週齢までしか行なっ ていないため, end stage の像が認められなかったも のと思われる。加齢と共に進行していく上述の病変は, chronic nephrosis and glomerulonephritis [21], progressive glomerulonephrosis [4], nephrosis $[2,23]$, nephropathy $[15,18]$, chronic nephritis
$[19,22]$, glomerulosclerosis [8], glomerulonephrosis [13], chronic progressive nephrosis [24], focal glomerular sclerosis [7] および chronic nephropathy [6]などの名で報告されている腎病変と同じ性格の ものであると考えられる。

71 週秢の皆ラットでは 2 例の皮髄境界部尿細管に石灰 化 cast が認められたが，雄ラットにはこのような像は 認められなかった。この種の変化は SD $[9,13,15]$, Wistar [22] 怙よび Donryu [20] などの系統でも倠 にだけ認められていることから，慢性腎症とは関係のな い変化であると考えられる。

\section{要 約}

ヤクルト研究所で維持している Fischer-344/Yit ラ ットの自然発生腎病変を $4,9,25,52$ 扣よび71週齢（52 週龄は雄の久を使用）の各時期に観察し，9週龄でラッ 卜慢性腎症の初期病変に相当すると考えられる变化を認 め, 52 週齢の雄でラット慢性腎症の特徵的所見とされる castを最初に認めた。すなわち，雄においては，9週 齢で主部尿細管上皮細胞に変性性変化が現われ, hyaline droplet や eosinophilic body が認められた。これ らの变化は 25 週齢が最も著明で， 1 部の上皮細胞に黄褐 色調を拈びるものがあった。また， H-E 染色により尿 細管内，上皮細胞内または系球体裹間腔内に，ときおり 赤血球様の小体を認めた。この小体と 1 部の eosinophilic body は hemoglobin 染色陽性であった。系球 体ではメサンジウム細胞の増加と基底膜の肥厚がわずか に認められた。52週齢で糸球体は軽度な線維化を伴い， 皮髄境界部の尿細管内に hyaline cast 形成, 主部尿 細管上皮のへモジデリン沈着と褐色の小体の出現および 間質に結合組織の軽度な増生とへモジデリン沈着が認め られる様になった。71週㱓では, 系球体病変, hyaline cast へモジデリン沈着および間質結合組織の増生が強 くなる傾向を示し，間質にリンパ球のわずかな浸潤が認 められた。雌では，尿細管上皮に护ける褐色の小体の出 現が雄に比べて強く恋められたが，他の病変の程度はき わめて軽度であった。また，71週龄の皮髄境界部の尿細 管内に石灰化した cast が認められた。

稿を終わるに臨み, 試薬を分与していただいた, 東京慈恵会医 科大学病理学教室田中寿子先生汇深甚の謝意を表します。

\section{文献}

[1] Andrew, W. and Pruett, D. (1957). Senile changes 
in the kidney of Wistar Institute rats. Am. J. Anat., 100, 51-69.

[2] Berg, B. N. (1965). Spontaneous nephrosis, with proteinuria, hyperglobulinemia, and hypercholesterolemia in the rat. Proc. Soc. Exp. Biol. Med., 119, 417-420.

[3] Boorman, G. A. and Hollander, C. F. (1973). Spontaneous lesions in the female WAG/Rij (Wistar) rat. J. Gerontol., 28, 152-159.

[4] Bras, G. and Ross, M. H. (1964). Kidney disease and nutritions in the rat. Toxicol. Appl. Pharmacol., 6. $247-262$.

[5] Bullock, B. C., Banks, K. L. and Manning, P. J. (1968). Common lesions in the aged rat. In The Laboratory Animal in Gerontological Research, National Academy of Scienses, Washington, 62-82.

[6] Coleman, G. L., Barthold, S. W., Osbaldiston, G. W., Foster, S. J. and Jonas, A. M. (1977). Pathological changes during aging in barrier-reared Fischer 344 male rats. J. Gerontol., 32, 258-278.

[ 7 ] Couser, W. A. and Stilmant, M. M. (1975). Mesangial lesions and focal glomerular sclerosis in the aging rat. Lab. Inv., 33, 491-501.

[8] Elema, J. D., Koudstaal, J., Lamberts, H. B. and Arends, A. (1971). Spontaneous glomerulosclerosis in the rat. Arch. Path. 91, 418-425.

[9] Foley, W. A., Jones, D. C. L., Osborn, G. K. and Kimeldorf, D. J. (1964). A renal lesion associated with diuresis in the aging Sprague-Dawley rat. Lab. Inv., 13, 439-450.

[10] Gray, J. E., Weaver, R. N. and Purmalis, A. (1974). Ultrastructural observation of chronic progressive nephrosis in the Sprague-Dawley rat. Vet. Path., 11, 153-164.

[11] Gray, J. E. (1977). Chronic progressive nephrosis in the albino rat. In CRC Critical Reviews in Toxicology, 115-144.

[12] Hirokawa, K. (1975). Characterization of age-associated kidney disease in Wistar rats. Mechanisms of aging and Development, 4, 301-316.

[13] 小林孝好・坂口弘 (1973). 老齢 SD-JCL ラットにみられ る腎炎様変化について。，日腎誌，15，221

[14] Lesser, G. T., Deutsch, S. and Markofsky, J. (1973). Aging in the rat: Longitudinal and cross-sectional studies of body compositions. Am. J. Physiol., 225, 1472-1478.

［15］村岡義博・伊藤真喜子・前田スミノ・林裕造 (1977). SDJCL ラット諸造器の加齡による組織学的変化について。 実験動物, 26, 1-12.

［16］二木力夫・菊地セイ子・高橋信子・高垣義男 (1974). ラッ 卜腎尿細管上皮にみられた異常所見について。実験動物, 23, 204 .

［17］尾上正治 - 内田和美・高橋徳太郎 - 草野信男 - 務台方彦 (1978). 加龄にともなうラットの腎の病理組織学的変化と 腎機能検查値の関係. 実験動物, 27, 405-412.

[18] Perry, S. W. (1965). Proteinuria in the Wistar rat. J. Path. Bact., 89, 729-733.

[19] Rapp, J. P. (1973). Age-related pathologic changes, hypertention, and 18-hydroxycorticosterone in rats selectively bred for high or low juxtaglomerularity. Lab. Invest., 28, 343-351.

[20］佐藤博 (1973). 飼料差によるWistar, SD, Donryu お よび Fischer ラットへの影響（3）・病理所見について. 実験動物, 25, 110-113.

[21] Simms, H. S. and Berg, B. N. (1957). Longevity and onset of lesions in male rats. J. Gerontol., 12, 244-252.

[22] Snell, K. C. (1967). Renal disease of the rat. In Pathology of Laboratory Rats and Mice. Cotchin, E. and Roe, F. J. C., editors, Blackwell sci. Pub., Oxford, 105-147.

[23］田中寿子・飯塚 壮 (1974). 長期飼育 SD-JCL おょひび Donryu-JCL ラットの病理組織学的検索. 実験動物, 23, 204.

[24] Weaver, R. N., Gray, J. E. and Schultz, J. R. (1975). Urinary proteins in Sprague-Dawrey rats with chronic progressive nephrosis. Lab. Ani. Sci., 25, 705710 . 


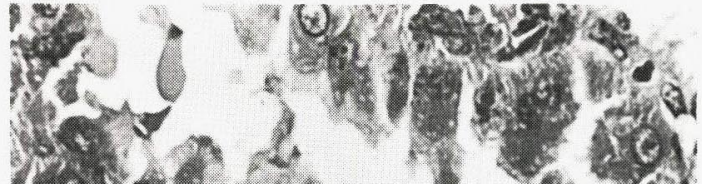

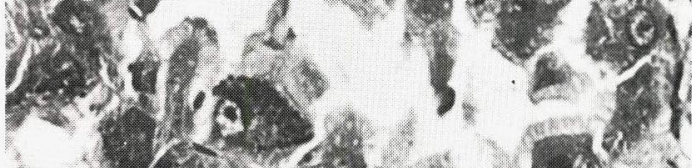

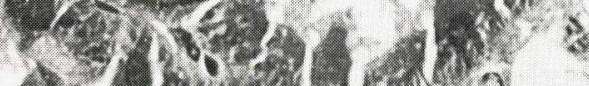
w di

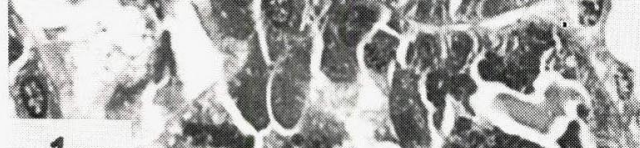

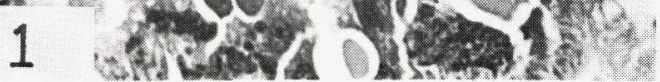

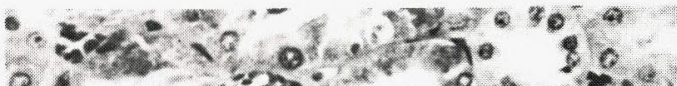
Q.

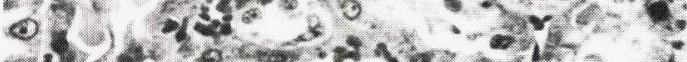

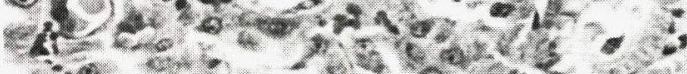

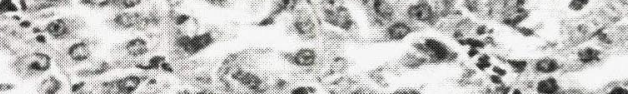
-

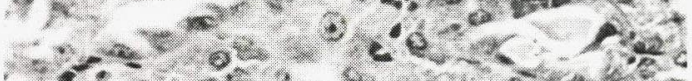

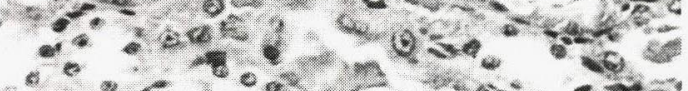

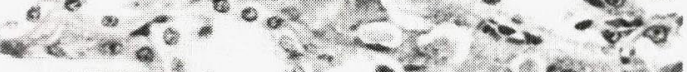

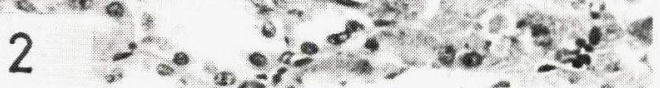

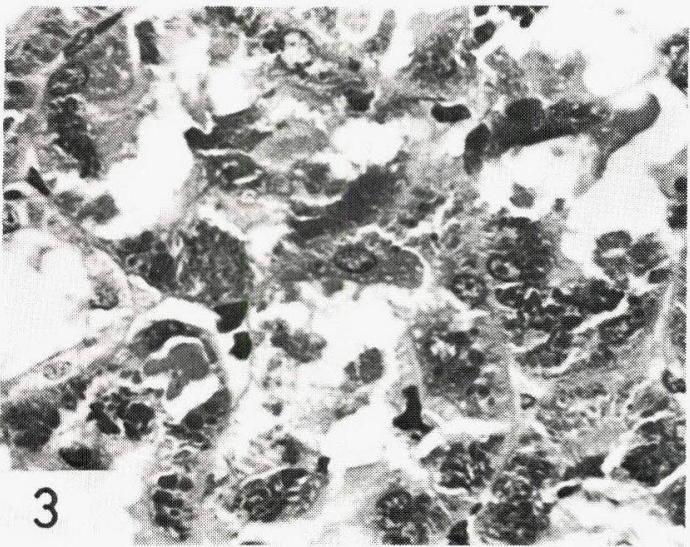
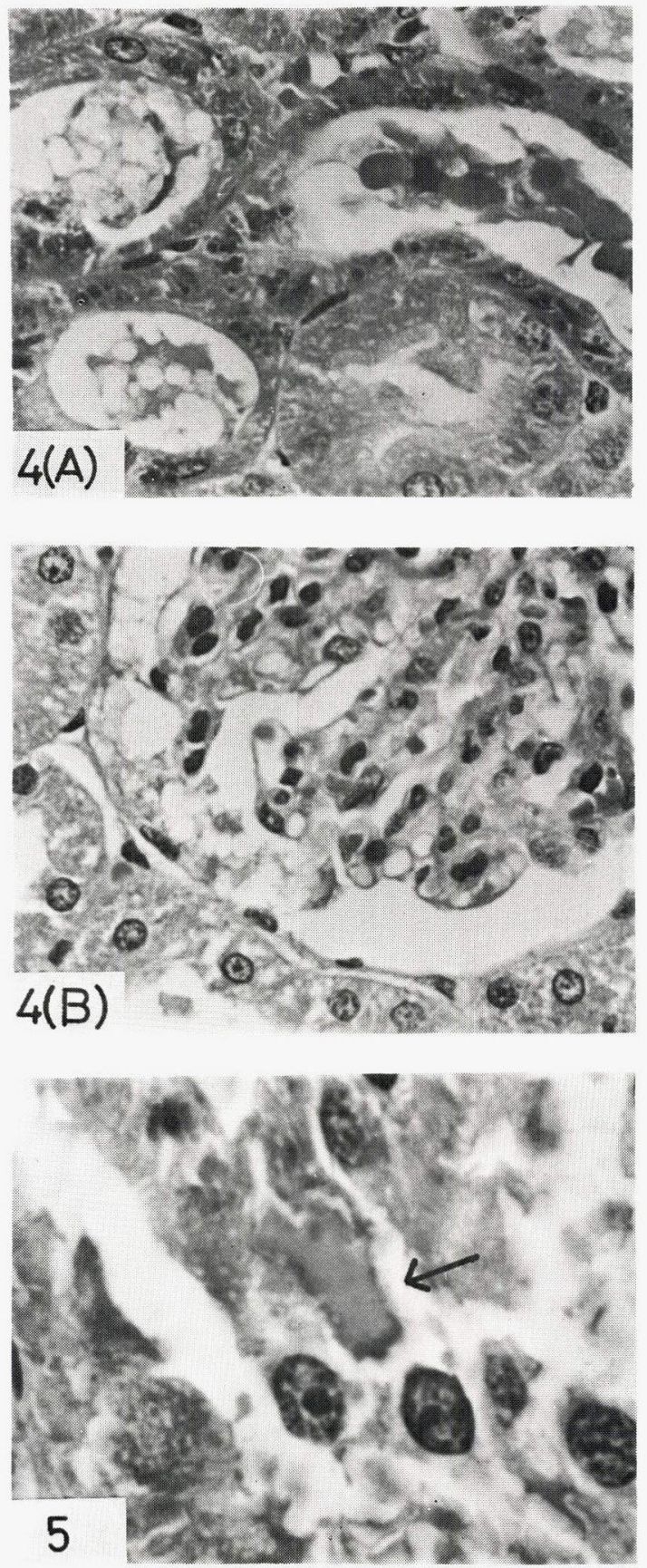

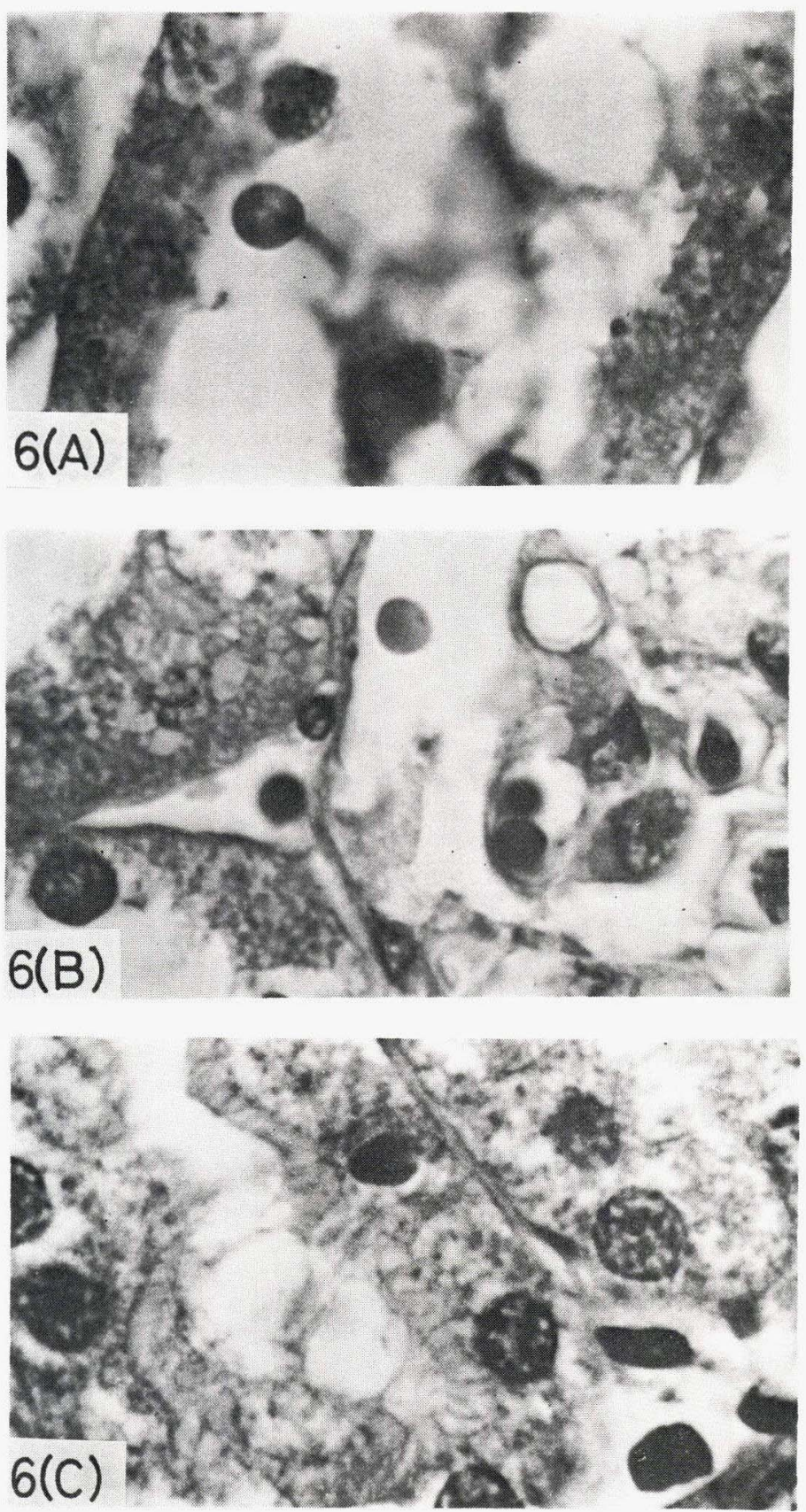

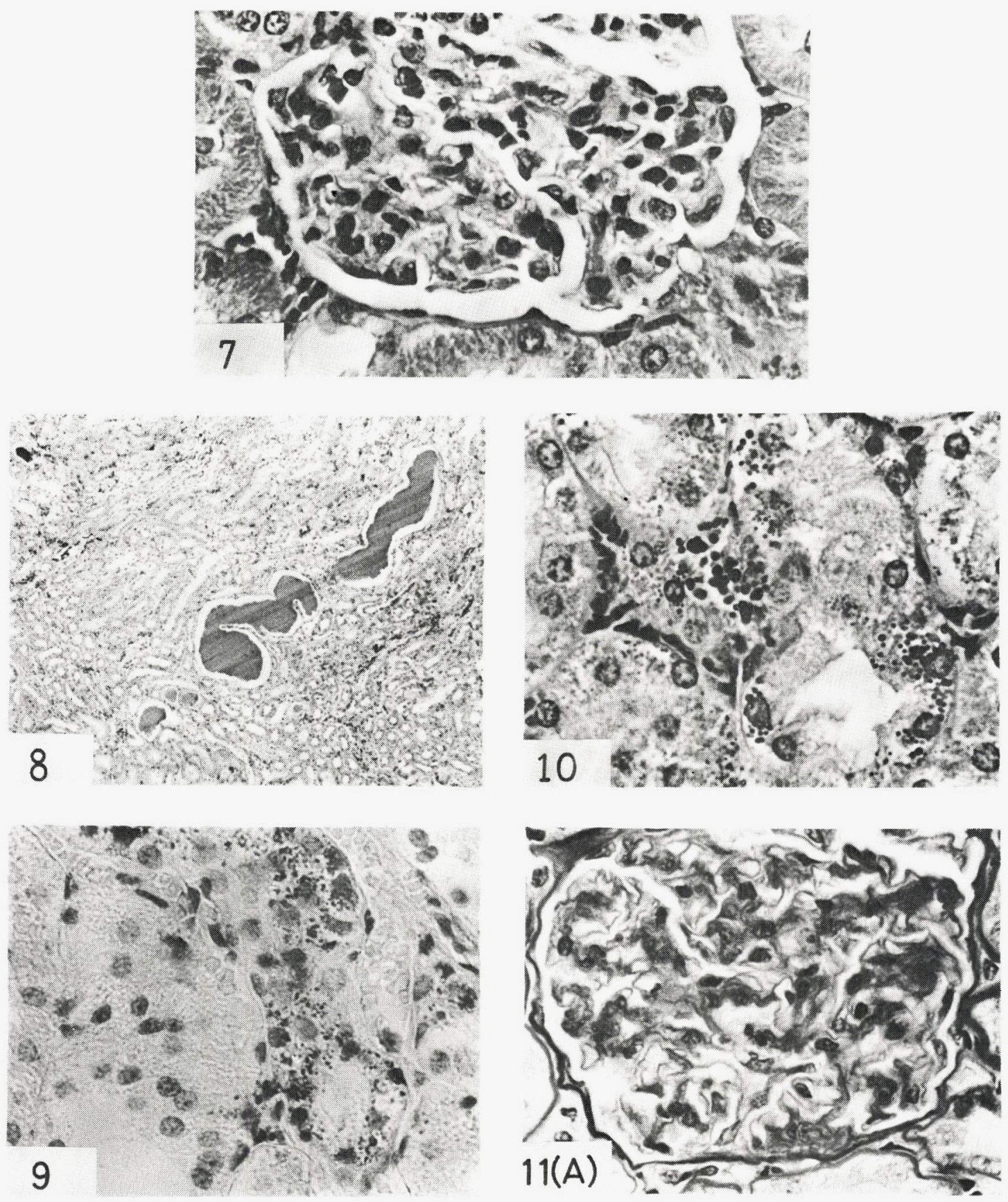

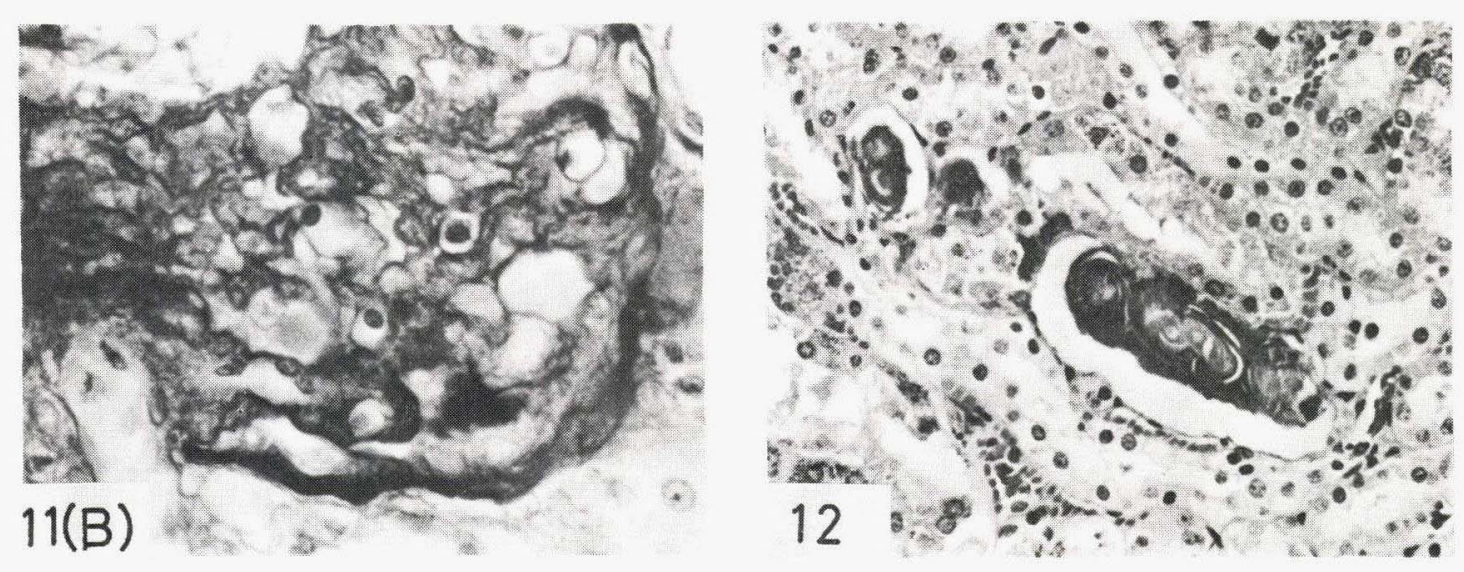

\section{Explanation of Figures}

Fig. 1. Cellular irregularity and hyaline droplets in proximal convoluted tubular epithelium found in 9-week-old male rat. $(\mathrm{H}-\mathrm{E}, \times 720)$

Fig. 2. Eosinophilic bodies in proximal convoluted tubular epithelium found in 9week-old male rat. (H-E, $\times 360)$

Fig. 3. More severe degeneration of epithelial cells than Fig. 1 in 9 -ween-old male rat. $(\mathrm{H}-\mathrm{E}, \times 720)$

Fig. 4. Reticulate substances in the affected tubulus (A) and in the Bowman's spaces (B) found in 9-week-old male rat. $(\mathrm{H}-\mathrm{E}, \times 720)$

Fig. 5. Yellowish-brown epithelial cell (arrow) in proximal convoluted tubular epithelium found in 25-week-old male rat. (H-E, $\times 1800)$

Fig. 6. Erythrocyte-like substance in the lumen (A), in the epithelial cell (B) or in the Bowman's space (C) found in 25-weekold male rat. $(\mathrm{H}-\mathrm{E}, \times 1800)$

Fig. 7. Increase of mesangial cells and thicke- ning of Bowman's capsule in glomerulus found in 25-week-old male rat. (H-E, $\times 700)$

Fig. 8. Hyaline casts in some dilated tubulus of corticomedullary area in 52-weekold male rat. $(\mathrm{H}-\mathrm{E}, \times 70)$

Fig. 9. Hemosiderin granules in proximal convoluted tubular epithelium found in 52week-old male rat. (Prussian blue, $x$ 700)

Fig. 10. Brown substances in proximal convoluted tubular epithelium found in 52week-old male rat. $(\mathrm{H}-\mathrm{E}, \times 700)$

Fig. 11. (A) Fibrosis of glomerulus and proximal convoluted tubulus with thickening of basement membranes in 52-week-old male rat. (PAS, $\times 700)$ (B) Adhesion of glomerular tufts and Bowman's capsule found in 52-week-old male rat. (PAS, $\times 700$ )

Fig. 12. Calcified casts in tubulus of corticomedullary area found in 71-week-old female rat. $(\mathrm{H}-\mathrm{E}, \times 350)$ 